The University of Akron

\title{
IdeaExchange@UAkron
}

Proceedings from the Document Academy

University of Akron Press Managed

June 2017

\section{Photo Synthesis: The Expatriate Family Album as Historiography}

Kamayani Sharma Ms

Independent, ubergonzo@gmail.com

Please take a moment to share how this work helps you through this survey. Your feedback will be important as we plan further development of our repository.

Follow this and additional works at: https://ideaexchange.uakron.edu/docam

Part of the Cultural History Commons, Photography Commons, Theory and Criticism Commons, and the Visual Studies Commons

\section{Recommended Citation}

Sharma, Kamayani Ms (2017) "Photo Synthesis: The Expatriate Family Album as Historiography," Proceedings from the Document Academy: Vol. 4 : Iss. 1 , Article 14.

DOI: https://doi.org/10.35492/docam/4/1/14

Available at: https://ideaexchange.uakron.edu/docam/vol4/iss1/14

This Article is brought to you for free and open access by University of Akron Press Managed at IdeaExchange@UAkron, the institutional repository of The University of Akron in Akron, Ohio, USA. It has been accepted for inclusion in Proceedings from the Document Academy by an authorized administrator of

IdeaExchange@UAkron.For more information, please contact mjon@uakron.edu, uapress@uakron.edu. 
Rifling through pictures of my childhood spent in West Asia as the child of Indian expatriates, I realized that these records of my personal past had become a prism through which to illuminate a period and place experienced by many other people. Photographs are like reliable alter egos of memories, rehearsing past events in vivid emotional detail with the added assurance that those events actually happened in a particular form. They are forensic documents offering affective modes of history writing - part of what the historian Pierre Nora termed lieux de mémoire that take "root in the concrete, in spaces, gestures, images and objects" (p. 7). I want to make a case for the possibilities of using snapshots as historiographical material through the form of the memoir; a method combining thick description, interviews and speculation suggested by Annette Kuhn works best for this. 
In this snapshot, from 1994, I have been shot turning to look at the remains of a sandcastle on a beach in Dubai, UAE. Going to the beach on weekend evenings was a family ritual when I was growing up and this picture is one among many that were taken during one of those excursions.

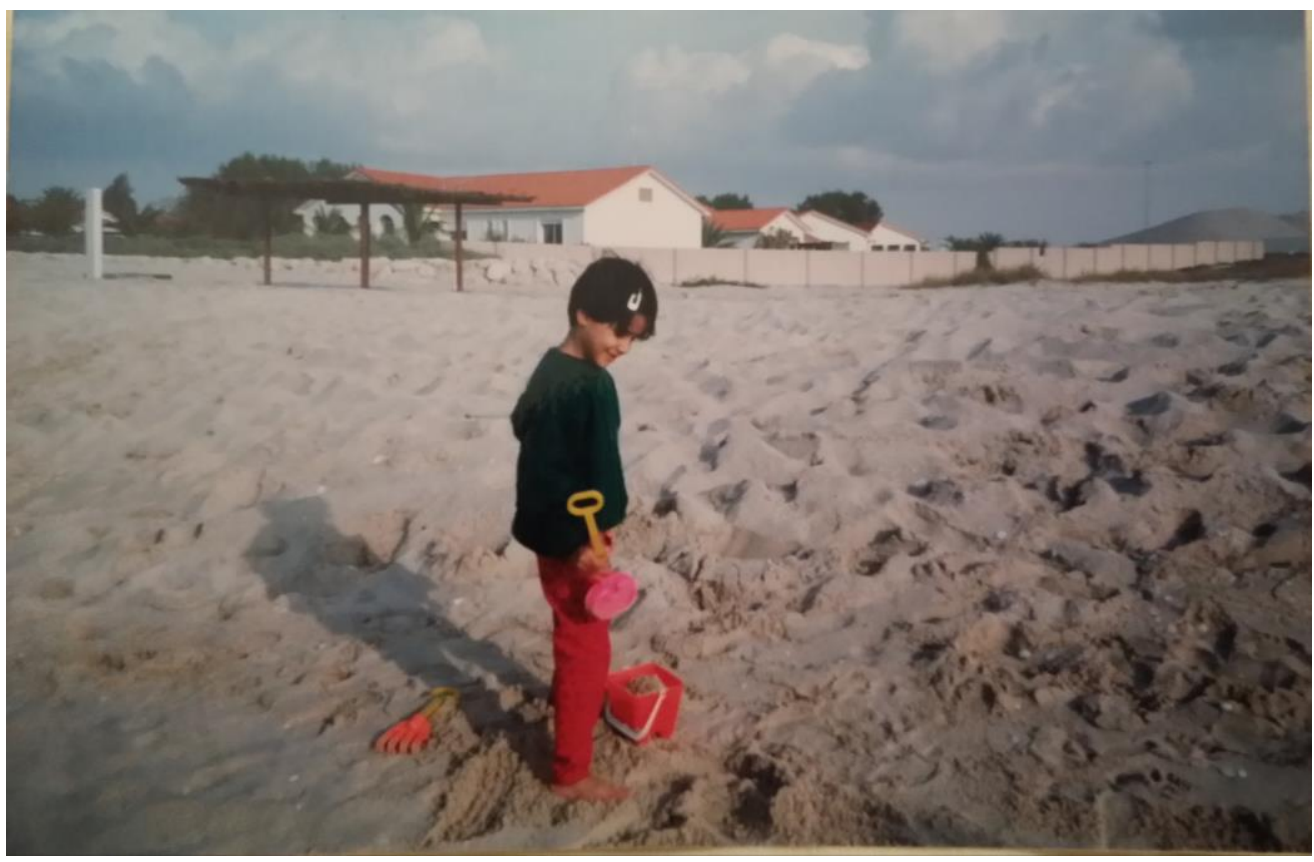

In the burgeoning urban jungle of early-90s Dubai, just before it exploded into the hyper-real geography it is today, there were few places to take children to, and the beach, free and open to all, was a favourite across classes. But not necessarily communities: certain beaches were frequented by the fewer Western expats and others by the dominant but lower class Asian ones, because of a highly stratified cosmopolitanism. Every child who has grown up in West Asia must have some of these "Me at the beach, age 4" photographs, simply because there weren't many places your parents could have taken you to at that age.

Despite this popularity of the beach, there is a conspicuous lack of people in the rather broad patch of background that is visible in this photograph. While I initially attributed this to my perhaps phantom memories of my father working weekends and our going to the beach on his days off when nobody else was around, he remembers differently, "I did have Friday off when you were growing up, but I think that this photograph was taken on a weekday or perhaps the wind put people off." 
The compositional finesse-wide-angled frame, centrality and 'candid' pose of the subject - indicate that the photographer, my father, had experience and talent in handling the camera. Clearly, I was a much-photographed child and my father an enthusiast of the medium. Cameras were relatively inexpensive in a Dubai on the cusp of its commodity boom-ads for the now-(in)famous Dubai Shopping Festival were everywhere-and incomes for middle-class expats were good enough to afford them.

The spades and bucket suggest knowledge, on the part of both my parents and myself, of Western childhood traditions. There was a wider expatriate community of Americans and Europeans who sold items regularly at thrift stores and garage sales. A familiarity with that cultural imaginary is unremarkable in a postcolonial, post-globalization context but the acquisition and use of the items by a South Asian child in the early 90s was made possible because of living in a territory that was constituted by a fragmented international mosaic.

Family snapshots are examples of the way in which the material traces of intimate lives behave as sites of collective remembrance and archives of shared history. Expatriate photographs become important repositories of social and cultural histories because they exemplify the twofold possibilities that the notion of "nostalgia" bears. Svetlana Boym writes, "The nostalgic desires to turn history into private or collective mythology, to revisit time like space, refusing to surrender the irreversibility of time that plagues the human condition" (p. 9). 
This second snapshot is from 1995. My thick jacket indicates that it is winter. I could not place this image at all. The mountain in the background reminded me of picnics in the lee of the Fujairah mountains and the urban oasis of Al Ain. It was my mother who filled in the blanks, "We'd gone to Al Ain with your father's colleague, early in the morning, with a packed lunch." She doesn't remember whether it was she or the colleague who took the picture but it is one of my few childhood photographs not taken by my father. Consequently, it is one of the rarer photographs that I have with him from that time. It is a bit awkwardly composed, slightly askew, with my father looking away as I look into the camera.

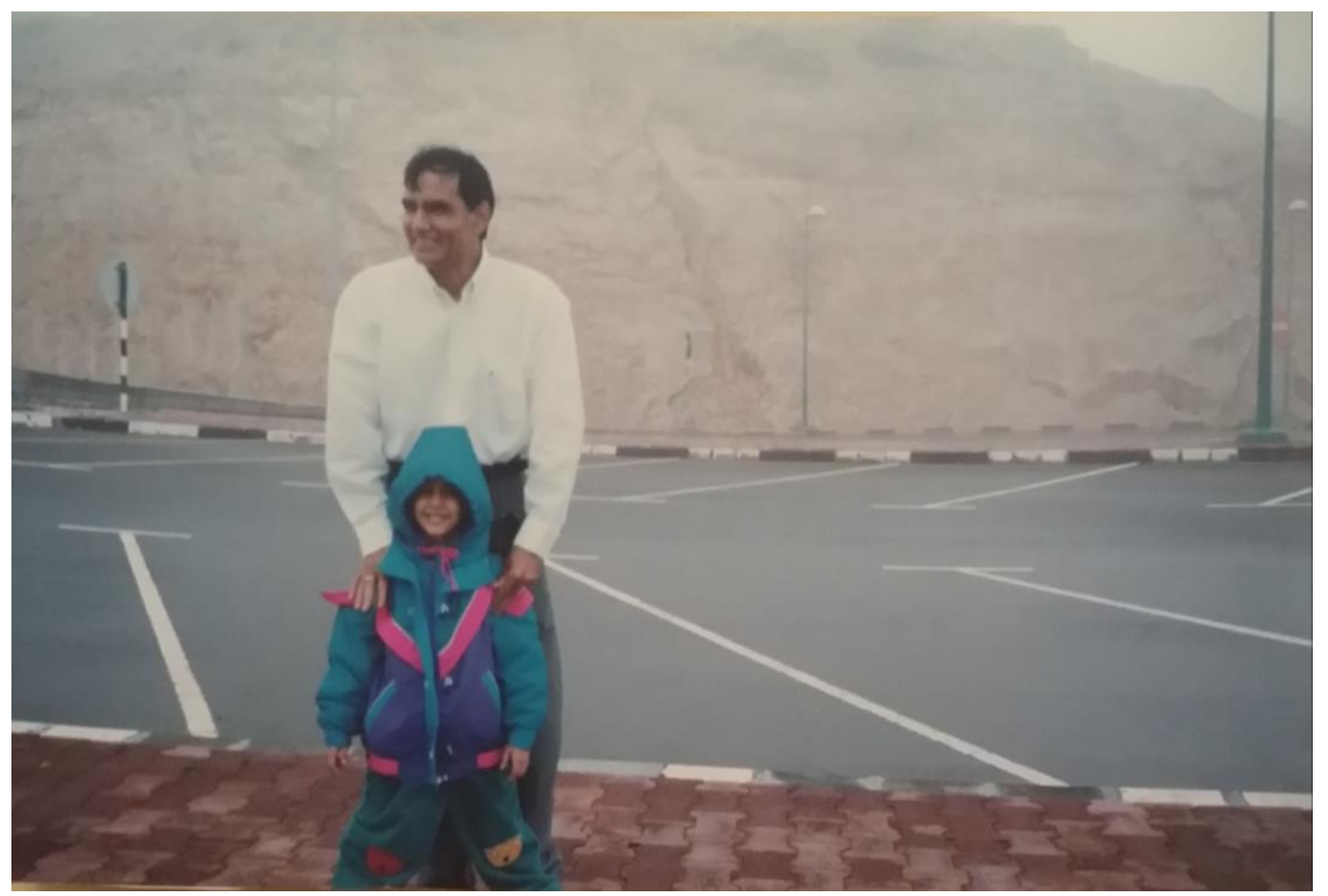

The hoary landscapes of places that one once lived in become inextricably intertwined with certain time periods in our lives and the world's, both impossible to return to. Public geographies start to rhyme with autobiographical histories. My mother likened the mountainous landscape to the one in our home state of Uttarakhand in India and commented on how this photograph would have been difficult to locate if not for the pavement and road markings. She and my father differed on the year in which it was taken, finally having to recount events in their biographical calendars to be able to determine the year. The expatriate imagination constantly swings between topographies and times, confusing one for the other or using them to pin down memories. 
I also find it necessary to point out how my parents' memories of my childhood, mediated through these photographs they took of me, is a staging of how personal memories are enmeshed with social ones. The parent-as-photographer or witness to their child's history being documented and participating in the nostalgia is as much inserting his or her autobiography into the social space of semantics generated by the photographs. Memories thicken and deepen when they are recognized as the offspring of multiple, simultaneous histories meeting and mating. 
This last image I want to look at is one from 1998, taken in Bahrain, where we shifted to the year before. It is a blurry, low-lit photo presumably taken at dusk. I have a strong suspicion that it was taken by my then-17-year-old brother, who didn't spend any time framing it properly. At 8 years old, sandcastling had been replaced by skating, and I sported that cringe-inducing staple of mid-to-late-90s childhoods worldwide, the bowl cut. Unlike Dubai, Bahrain doesn't have sandy beaches, so we would go instead to the children's park seen in the background.

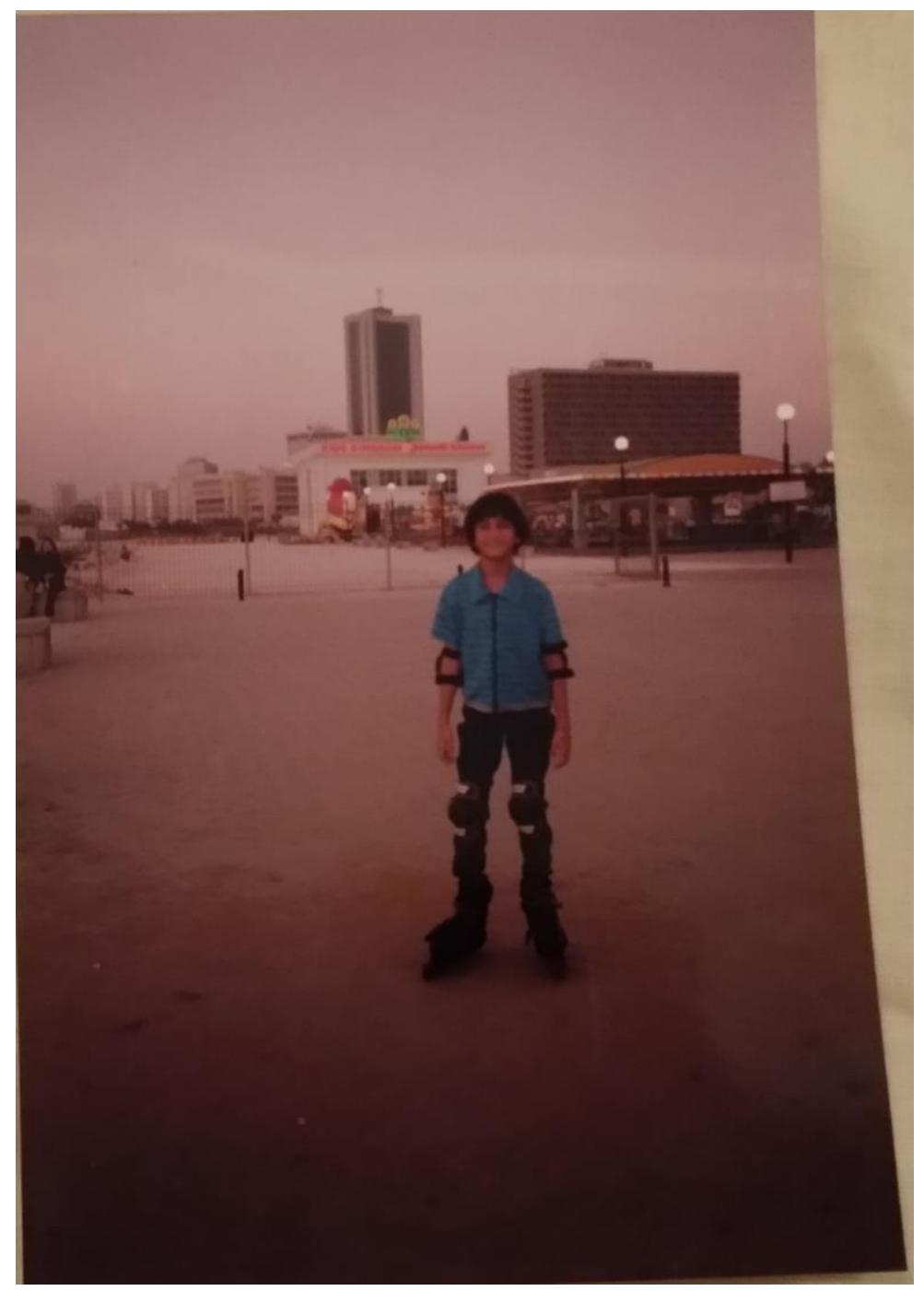

There is a very strong sense of melancholia emanating from this picture despite or perhaps due to both the suffused violet light and its ordinariness. When Geoffrey Batchen underscores the "determined banality" (p. 124) of family snapshots and 
the challenge they pose to historiographies of visual culture, he seems to be speaking particularly about photographs of this sort, that are interesting neither compositionally nor thematically, at least on the surface. My brother has no memory of this picture, and neither of my parents could have taken it because of its clumsy quality. The elusiveness of photos such as these, not rare in family collections, taken by a close relative who is thus forgiven his/ her lack of skill because of the specialness of the moment, is worth remarking upon.

Expatriate childhoods, especially, intensify this twinning of space and time: we can never return to earlier selves; we can never return to those lost places that have been transformed since we last lived there. In the case of expatriate childhoods, the piquancy of those details is emphasised by the impermanence of the arrangements, the always-lingering specter of return to the homeland. I haven't skated in more than a decade, do not wear my hair as in the image, and have not visited the park for a long time. During my last visit, driving past, I knew that it no longer looked the way it does here. Just as the city's architecture has responded to the demands of developmentalist pressures, I too have responded to the claims on performances of gender and age that were made on me over the years. The histories of public spaces and private bodies do not operate in independent technological regimes.

The expatriate photograph, negotiating not only between past and present but also between this space and that, resists easy absorption into the reactionary logic of "restorative" nostalgia. This is the kind of yearning that is based on wanting to return to mythical halcyon days and homelands, the stuff of insurrections and revolutions. Instead, these snapshots lend themselves to a half-wistful, halfcritical "reflective" nostalgia, the mood subjunctive rather than imperative. This sort of backward glance, as Boym reiterates, "does not follow a single plot but explores ways of inhabiting many places at once and inhabiting different time zones. It loves details, not symbols" (p. 13).

Snapshots from personal albums, soaked in intensely specific details, function as a bridge between little narratives and grand ones, those of the self and those of the other. They reveal the concentric circuits that lead from family to world, and pave new paths towards ostensibly known geographies and histories. The expatriate childhood is one that, in its movements between spaces, and times, provides a comfortable background against which to curate a montage that illuminates the possibilities for our own lives to become sites of knowledge production. 


\section{References}

Batchen, G. (2008). Snapshots. Photographies, 1(2), 121-142. doi: $10.1080 / 17540760802284398$

Boym, S. (2007). Nostalgia and its discontents. The Hedgehog Review, 9(2), 718. Retrieved from http://www.iasc-culture.org/THR/hedgehog_review_2007Summer.php

Kuhn, A. (2007). Photography and cultural memory: A methodological exploration. Visual Studies, 22(3), 283-292. doi: 10.1080/14725860701657175

Nora, P. (1989). Between memory and history: Les lieux de mémoire. Representations, 26, 7-24. doi: 10.2307/2928520 